\title{
SEPSIS NEONATAL PADA KASUS DEFEK SEPTUM VENTRIKEL
}

\author{
${ }^{1}$ Loretta C. Wangko \\ ${ }^{2}$ Erling D. Kaunang \\ ${ }^{1}$ Bagian Ilmu Penyakit Jantung dan Pembuluh Darah Fakultas Kedokteran \\ Universitas Sam Ratulangi Manado \\ ${ }^{2}$ Bagian Ilmu Kesehatan Anak Fakultas Kedokteran Universitas Sam Ratulangi Manado \\ Email: lorettawangko@yahoo.com
}

\begin{abstract}
Neonatal sepsis is a clinical syndrome characterized by signs and symptoms of infection, with or without bacteriemia, that occurs in the first month of life. Neonatal sepsis is still a main factor of morbidity and mortality in newborns. We reported a case of a male newborn with septic risks: viscous amniotic fluid with a bad odour, maternal intrapartum fever $\left(\geq 38^{0} \mathrm{C}\right)$, urinary tract infection, and fluor albus. A chest $\mathrm{x}$-ray showed some infiltration in the left paracardial region and a normal heart; and was interpreted to be pneumonia. A working diagnosis was an aterm neonatus with neonatal sepsis and neonatal pneumonia. Ventricle septal defect (VSD) without congestive heart signs was diagnosed by using an echocardiography. The patient was treated for a neonatal sepsis and given antibiotics from the first day of admission due to the neonatal septic signs. During observation, the patient was getting better, and his activities and reflexes improved without dyspnea. Conclusion: Based on all the tests performed, the diagnosis of this patient was neonatal sepsis, VSD, and pneumonia neonatal. The prognosis related to neonatal pneumonia in this case was good due to the early use of antibiotics. The prognosis of a small perimembrane VSD is dubia ad bonam because in $50 \%$ of cases it can spontaneously oclude in the second year.
\end{abstract}

Keywords: newborn, sepsis, pneumonia, ventricle septal defect.

\begin{abstract}
Abstrak: Sepsis neonatal ialah suatu sindrom klinis yang ditandai oleh gejala dan tanda-tanda infeksi dengan atau tanpa diikuti oleh bakteremia yang terjadi pada bulan pertama kehidupan. Sepsis neonatal masih merupakan penyebab utama morbiditas dan mortalitas pada bayi-bayi baru lahir. Kami melaporkan kasus bayi laki-laki baru lahir dengan resiko sepsis yaitu:cairan ketuban kental dan berbau busuk, demam intrapartum maternal $\left(\geq 38^{\circ} \mathrm{C}\right)$, infeksi saluran kencing, dan keputihan. $\mathbf{X}$-foto toraks memperihatkan adanya infiltrat di parakardial kiri, jantung dalam batas normal, dan diinterpretasi sebagai pneumonia. Diagnosis kerja ialah neonatus cukup bulan, sepsis neonatal, dan pneumonia neonatal. Diagnosis defek septum ventrikel (DSV) ditegakkan melalui ekokardiografi tanpa tanda-tanda gagal jantung kongestif. Pasien diberikan penanganan sepsis dan pemberian terapi antibiotik empiris sejak hari pertama perawatan karena secara klinis telah ditemukan tanda-tanda sepsis neonatal. Selama observasi, pasien memperlihatkan perbaikan yang nyata dimana aktivitas dan refleks membaik tanpa disertai sesak napas. Simpulan: Berdasarkan hasil pemeriksaan yang dilakukan, diagnosis yang ditegakkan ialah sepsis neonatal disertai DSV dan pneumonia neonatal. Prognosis pneumonia neonatal kasus ini baik oleh karena pemakaian antibiotika sejak dini. Prognosis DSV kecil perimembran ialah dubia ad bonam karena 50\% dapat menutup spontan pada usia dua tahun.
\end{abstract}

Kata kunci: bayi baru lahir, sepsis, pneumonia, defek septum ventrikel. 
Sepsis neonatal adalah suatu sindrom klinis yang ditandai oleh gejala dan tanda-tanda infeksi dengan atau tanpa diikuti oleh bakteremia yang terjadi pada bulan pertama kehidupan. ${ }^{1}$ Sepsis neonatal masih merupakan penyebab utama morbiditas dan mortalitas pada bayi-bayi baru lahir. Di negara berkembang diperkirakan satu juta kematian (10\% dari angka kematian pada anak) setiap tahunnya dihubungkan dengan infeksi yang didapat pada masa neonatal (028 hari kehidupan). ${ }^{2-4}$ Data National Neonatal Perinatal Database tahun 2002-2003 memperlihatkan sebanyak 30 kasus per 1000 kelahiran hidup. ${ }^{1}$

Insidens sepsis di negara berkembang masih cukup tinggi (1,8-18/1000) dibandingkan dengan negara maju (1-5/1000 kelahiran). Resiko sepsis pada bayi lakilaki dua kali lebih besar dibandingkan bayi perempuan. Di Asia Tenggara insidens sepsis berkisar 2,4-16/1000 kelahiran hidup. Pada Divisi Neonatologi dari Departemen Kesehatan Anak Fakultas Kedokteran/ Rumah Sakit Cipto Mangunkusumo (RSCM) tahun 2003 sepsis ditemukan $56,1 / 1000$ kelahiran hidup. Walaupun infeksi bakteri berperan penting pada sepsis neonatal, namun adanya infeksi virus juga perlu dipertimbangkan. Dari tahun ke tahun, insidens sepsis tidak banyak mengalami peningkatan, sebaliknya angka kematian menunjukkan perbaikan yang bermakna. Angka kematian dapat mencapai 50\% pada bayi yang tidak diobati. ${ }^{2,5}$

Pneumonia neonatal ialah inflamasi yang terjadi pada parenkim paru. Pneumonia merupakan penyebab penting dari infeksi neonatal dengan angka morbiditas dan mortalitas yang bermakna, terutama di negara-negara berkembang. Dewasa ini, WHO memperkirakan hampir 800.000 kematian neonatal yang terjadi setiap tahun akibat infeksi akut saluran napas.,

Penyakit jantung bawaan non-sianotik merupakan bagian terbesar dari seluruh penyakit jantung bawaan (PJB). Defek septum ventrikel (DSV) merupakan kelainan yang paling sering ditemukan, dan menca- kup 30 \% dari semua PJB. ${ }^{8,9}$

Klasifikasi DSV menurut lokasi defek yaitu: DSV perimembran, DSV muskular, dan DSV subarterial. Menurut ukurannya, DSV diklasifikasikan menjadi DSV kecil (luas defek $<5 \mathrm{~mm}^{2} / \mathrm{m}^{2}$ luas permukaan tubuh); sedang (luas defek $5-10 \mathrm{~mm}^{2} / \mathrm{m}^{2}$ luas permukaan tubuh); dan besar (luas defek $>1 / 2$ diameter aorta atau $>10 \mathrm{~mm}^{2} / \mathrm{m}^{2}$ luas permukaan tubuh). DSV lebih sering ditemukan pada perempuan (56\%). ${ }^{10-12}$

Manifestasi klinis DSV sangat tergantung pada ukuran defek. Defek kecil biasanya asimtomatik, sedangkan defek sedang dan besar dapat menunjukkan gejala gagal jantung kongestif dengan sesak, berkeringat, gagal tumbuh, serta gejala-gejala infeksi saluran pernafasan. ${ }^{9,13}$

\section{LAPORAN KASUS}

Seorang bayi laki-laki, lahir di BLU RSUP Prof R.D. Kandou Manado pada 28 Juni 2012 jam 01.10 WITA secara spontan per vaginam dengan berat badan lahir 2500 gram, panjang badan $45 \mathrm{~cm}$, skor APGAR 5-7.

\section{Riwayat kehamilan dan persalinan}

Kasus ini merupakan kehamilan pertama dari suami pertama. Ibu tidak mengingat hari pertama dari haid terakhirnya. Ibu tidak memeriksakan kehamilan secara teratur dan tidak mendapat imunisasi tetanus. Selama kehamilan, ibu mempunyai kebiasaan minum alkohol setiap hari kirakira $400 \mathrm{ml}$ dan merokok sekitar 5-6 batang per hari. Ibu mempunyai riwayat demam tinggi beberapa bulan terakhir saat kehamilan yang diikuti nyeri saat buang air kecil, serta riwayat keputihan berulang sebelum dan selama kehamilan. Sebelum melahirkan, ibu mengalami pecah ketuban satu hari sebelum masuk rumah sakit. Ibu juga meminum obat-obat tradisional selama kehamilan. Riwayat trauma selama kehamilan disangkal dan tidak mempunyai hewan peliharaan di rumah. 
Hasil pemeriksaan fisik, pemeriksaan penunjang, diagnosis, pemberian terapi, dan follow up

\section{Hari rawat ke-1}

Berat badan 2.500 gram, panjang badan $45 \mathrm{~cm}$, keadaan umum aktifitas fisik dan refleks menurun. Pada tanda vital ditemukan denyut jantung 148x/menit, pernapasan 68x/menit, dan suhu badan $38,4^{\circ} \mathrm{C}$. Toraks berbentuk simetris, dengan retraksi subkostal minimal. Pada pemeriksaan jantung didapatkan denyut jantung $148 \mathrm{x} /$ menit, bunyi jantung regular, bising pansistolik grade 2/6, dengan pungtum maksimum di sela iga III garis parasternal kiri. Pada pemeriksaan paru suara pernapasan bronkovesikuler, ronki basah halus minimal pada lapangan paru basal kiri, dan tidak ditemukan wheezing. Ekstremitas bagian akral hangat, capillary refill time normal (CRT) $<2$ detik, dan tidak terdapat sianosis dan deformitas.

Skor Ballard 36 yaitu sesuai dengan 38-40 minggu usia kehamilan. Kurva pertumbuhan dan perkembangan Battaglia dan Lubchenco menunjukkan bayi sesuai dengan usia kehamilan.

Faktor risiko sepsis yang ditemukan ialah cairan ketuban kental dan berbau busuk, demam intrapartum maternal $\left(\geq 38^{\circ} \mathrm{C}\right)$, infeksi saluran kencing, dan fluor albus.

Foto toraks memperihatkan adanya infiltrat di parakardial kiri, jantung dalam batas normal, dan diinterpretasi sebagai pneumonia. Hasil laboratorium memperlihatkan hemoglobin $15.5 \mathrm{~g} / \mathrm{dL}$, hematokrit $46.9 \%$, leukosit $22.300 / \mathrm{mm}^{3}$, trombosit 263.000/ $\mathrm{mm}^{3}$, hitung jenis $0 / 3 / 20 / 61 / 11 / 5$, ratio IT 0,25 (harga normal $<0,2$ ), apusan darah tepi dalam batas normal untuk neonati, CRP $22 \mathrm{mg} / \mathrm{dL}$, dan glukosa darah $102 \mathrm{gr} / \mathrm{dL}$.

Diagnosis yang ditegakkan ialah neonatus cukup bulan disertai sepsis neonatal, pneumonia neonatal, dan suspek DSV.

Terapi yang diberikan yaitu oksigen 5 L/menit dengan headbox, IVFD D10\% 6-7 mikrodrips per menit, amoxicillin 2 x 125 mg injeksi intravena, gentamicin $12,5 \mathrm{mg}$ injeksi intravena/36 jam, vitamin K $1 \mathrm{mg}$ intramuskular, dan rawat tali pusat. Asupan oral dihentikan.

\section{Hari rawat ke-2}

Pasien tampak sesak dan disertai demam (suhu tubuh $37,9^{0} \mathrm{C}$ ). Keadaan umum tampak aktivitas dan refleks masih menurun. Tanda vital denyut jantung 124 kali/menit, pernapasan 64 kali/menit, suhu tubuh $37,9^{\circ} \mathrm{C}$, dan berat badan 2.300 gram. Pemeriksaan toraks pernapasan simetris dan retraksi subkostal minimal. Pada pemeriksaan paru suara pernapasan bronkovesikuler, ronki basah halus minimal pada lapangan paru basal kiri, tetapi tidak ditemukan wheezing.

Hasil EKG tidak memperlihatkan kelainan dan disarankan untuk ekokardiografi.

Terapi yang diberikan yaitu oksigen nasal 0,5-1 L/menit, IVFD KA-EN 4B 161 $\mathrm{ml}$ 8-9 tetes/menit, D40\% $39 \mathrm{ml}$ (cairan 80 $\mathrm{ml} / \mathrm{kgBB} / \mathrm{hari}$, Glucose Infusion Rate 6), amoxicillin 2 x 125 mg injeksi intravena, gentamicin 12,5 mg injeksi intravena /36 jam, ASI 8 x 3-4 cc dengan nasogastric tube (10-20 cc/kgBB/hari), dan rawat tali pusat.

\section{Hari rawat ke- 3}

Pasien masih sesak, tidak demam (suhu tubuh $36,5^{0} \mathrm{C}$ ). Dilakukan ekokardiografi dengan hasil defek septum ventrikel perimembrane outlet (DSV PMO) kecil, dan dianjurkan untuk ekokardiografi ulangan satu tahun kemudian. Diagnosis yang ditegakkan ialah neonatus cukup bulan, sepsis neonatal, pneumonia neonatal, dan DSV. Terapi yang diberikan yaitu oksigen nasal 0,5-1 L/menit, IVFD KA-EN 4B $49 \mathrm{ml}, \mathrm{D} 40 \%$ 49,5 ml, KCl $5 \mathrm{ml} 8-9$ tetes/menit, $\mathrm{Ca}$ Gluconas 13,5 ml, aminosteril $6 \% \quad 83 \mathrm{ml}$ (cairan 100 $\mathrm{ml} / \mathrm{kgBB} / \mathrm{hari}$, Glucose Infusion Rate 6, Protein $2 \mathrm{gr} / \mathrm{kgBB} /$ hari), amoxicillin $2 \mathrm{x}$ $125 \mathrm{mg}$ injeksi intravena, gentamicin 12,5 mg injeksi intravena /36 jam, ASI 8 x 6-7 cc (20 cc/kgBB/hari), dan rawat tali pusat.

\section{Hari rawat ke-5}

Dilakukan pemeriksaan darah lengkap 
dengan hasil hemoglobin 13,07 g/dL, hematokrit 36,94\%, leukosit $14.460 / \mathrm{mm}^{3}$, dan trombosit $9.000 / \mathrm{mm}^{3}$. Transfusi trombosit diberikan sebanyak 22 cc.

\section{Hari rawat ke-6}

Pasien masih sesak, suhu tubuh $37^{\circ} \mathrm{C}$. Diberikan antibiotika ceftazidime 2 x 125 mg dan amikasin 2 x 20 mg intravena, serta transfusi trombosit ulangan sebanyak 22 cc.

\section{Hari rawat ke-7}

Pasien tidak sesak lagi, pernapasan 60x/menit, tidak terdapat retraksi subkostal, dan tidak ditemukan ronki basah halus pada lapangan paru basal kiri.

Pemberian antibiotika dilanjutkan, dan diberikan transfusi trombosit ulangan sebanyak 22 cc.

\section{Hari rawat ke-8}

Dilakukan pemeriksaan darah lengkap dengan hasil hemoglobin 8,5 g/dL, hematokrit $24,5 \%$, leukosit $7.700 / \mathrm{mm}^{3}$, dan trombosit 226.000/. $\mathrm{mm}^{3}$.

Pemberian antibiotika dilanjutkan dan diberikan transfusi packed red cells 22 сc dengan furosemid $1 \mathrm{mg}$ intravena pre transfuse, dilanjutkan pada hari rawat ke-9.

\section{Hari rawat ke-10}

Hasil pemeriksaan darah lengkap hemoglobin $14.5 \mathrm{~g} / \mathrm{dL}$, hematokrit 34,5\%, leukosit $17.700 / \mathrm{mm}^{3}$, trombosit $228.000 /$ $\mathrm{mm}^{3}$. Pemeriksaan CRP menunjukkan hasil negatif, dan kultur darah steril.

Pemberian antibiotik (cetazidime and amikasin) dihentikan dan penderita dipulangkan dari rumah sakit.

Disarankan untuk harus segera berobat bila pasien mengalami infeksi saluran napas akut dan ekokardiografi ulangan satu tahun kemudian.

\section{BAHASAN}

Pada pasien ini diagnosis bayi sesuai masa kehamilan berdasarkan anamnesis dan pemeriksaan fisik. Pada anamnesis ditemukan ibu tidak mengingat hari pertama dari haid terakhirnya, tetapi pada pemeriksaan fisik berdasarkan Ballard's score (skor 36) ditemukan lipatan telapak kaki, genitalia eksterna, jumlah jaringan payudara, daun telinga (bentuk dan kekakuannya) sesuai dengan 38-40 minggu usia kehamilan. Berdasarkan kurva Battaglia dan Lubchenco (berhubungan dengan berat badan lahir dan periode gestasi), pasien dengan usia kehamilan 38 minggu dan berat badan lahir 2500 gram berada dalam 10 sampai 90 persentil termasuk neonatal sesuai masa kehamilan. ${ }^{14}$

Pasien didiagnosis dengan sepsis neonatal berdasarkan anamnesis, pemeriksaan fisik dan pemeriksaan penunjang lain. Sepsis neonatal didefinisikan sebagai sindrom klinis yang disebabkan oleh masuknya mikroorganisme ke dalam aliran darah pada bulan pertama kehidupan. Sepsis neonatal menyebabkan infeksi yang invasif pada aliran darah, ditandai dengan ditemukan bakteri pada cairan tubuh seperti darah, cairan sumsum tulang, atau urin.,15

Pada sepsis awitan dini terdapat berbagai faktor risiko yang dikelompokkan atas mayor dan minor. Faktor risiko mayor terdiri atas ketuban pecah dini $>18$ jam, demam pada ibu saat intrapartum $>38^{\circ} \mathrm{C}$, korioamnionitis, bunyi jantung janin $>160$ denyut per menit, serta cairan ketuban kental dan berbau busuk. Faktor risiko minor yaitu ketuban pecah dini $>12$ jam, demam pada ibu $>37,5^{\circ} \mathrm{C}$, skor APGAR yang rendah ( 1 menit $<5$; 5 menit $<7$ ), bayi berat badan lahir sangat rendah $(<1500 \mathrm{~g})$, usia kehamilan <37 minggu, fluor albus pada ibu yang tidak diobati, multigravida, dan ibu yang diduga menderita infeksi saluran kemih atau infeksi saluran kemih yang tidak diobati. $^{16,17}$ Pemeriksaan yang dianjurkan sebagai penanda sepsis yaitu jumlah leukosit $\left(<5000 / \mathrm{mm}^{3}\right.$ atau $\left.>25000 / \mathrm{mm}^{3}\right)$, jumlah trombosit $\left(<100.000 / \mathrm{mm}^{3}\right)$, perbandingan IT (perban-dingan netrofil yang belum matang dengan netrofil total) $>0,2$, dan CRP $>1 \mathrm{mg} / \mathrm{dL}^{2}$ Diagnosis dapat dipastikan bila didapatkan adanya satu faktor risiko mayor dan dua faktor risiko minor. Diagnosis sepsis harus ditegakkan tanpa menunggu hasil kultur darah. Patokan 
angka kultur darah pada neonati berkisar 25-54\%. Rapid immunological techniques seperti tes CRP dapat membantu dalam menegakkan diagnosis sepsis. Kultur darah untuk mengisolasi kuman patogen tetap merupa-kan baku emas dalam menentukan diagnosis sepsis, akan tetapi hasilnya membutuhkan waktu sekitar 2-5 hari sehingga diperlukan terapi empiris awal terhadap kecurigaan sepsis.

Trombositopenia sering ditemukan pada sepsis neonatorum. Sekitar $60 \%$ bayi baru lahir yang terbukti infeksi mengalami trombositopenia dengan jumlah trombosit $<100.000 /$ uL. Mekanisme yang mendasarinya dimungkinkan oleh produksi yang berkurang, peningkatan penghancuran, dan sekuestrasi pada limpa yang membesar. Diduga mekanisme utama yang berperan dalam hal terjadinya trombositopeni pada sepsis neonatal ialah penghancuran trombosit yang dipercepat. ${ }^{2,18,19}$

Anemia neonatal didefinisikan konsentrasi hemoglobin $(\mathrm{Hb})$ atau hematokrit lebih besar dari 2 standar deviasi di bawah rata-rata usia paska kelahiran. Pada bayi matur, nilai $\mathrm{Hb}$ dari 14,6-22,5 g/dL saat lahir menurun sampai 10-12 g/dL pada usia 8-10 minggu. Setelah mencapai nilai terendah, $\mathrm{Hb}$ akan meningkat secara bertahap dan akhirnya mencapai nilai $\mathrm{Hb}$ dewasa dalam dua tahun pertama setelah kelahiran. Anemia neonatal bisa terjadi karena kehilangan darah, penurunan produksi eritrosit, atau peningkatan penghancuran eritrosit. Patofisiologi dari anemia akibat inflamasi sangat rumit dimana terjadi penurunan produksi eritropoietin, kegagalan respon sumsum tulang terhadap eritropoietin, dan penurunan perlangsungan hidup eritrosit. Anemia biasanya ringan; penurunan kadar $\mathrm{Hb}$ jarang di bawah 8g/dL. ${ }^{16}$ Pada hari perawatan ke-8, terjadi penurunan $\mathrm{Hb}$ yang diakibatkan oleh sepsis sehingga pasien diberikan transfusi.

Kasus ini diklasifikasikan sebagai sepsis awitan dini neonatal sesuai dengan gejala klinis yang terjadi $<72$ jam dan riwayat adanya dua faktor risiko mayor yaitu cairan ketuban yang kental dan berbau busuk, demam pada ibu saat intra- partum $>38^{\circ} \mathrm{C}$, disertai dua faktor risiko minor yaitu infeksi saluran kemih dan fluor albus. Gejala klinis yang ditemukan yaitu gangguan pada sistem pernapasan (pernapasan $68 \mathrm{kali} /$ menit), sistem metabolik (suhu tubuh $38,4^{\circ} \mathrm{C}$ ), sistem neurologik (penurunan aktivitas dan refleks), dan sistem hematologik (trombositopenia pada hari ke-5). Pada pemeriksa-an penanda sepsis ditemukan perbandingan IT 0, 25, dan pemeriksaan CRP $22 \mathrm{mg} / \mathrm{dL}$ serta trombositopeni. Dengan terdapatnya dua faktor risiko baik mayor maupun minor, disertai gejala klinis yang melibatkan empat sistem, ditambah dengan tiga pemeriksaan klinis yang bermakna, maka diagnosis yang ditegakkan ialah sepsis neonatal. ${ }^{2,5}$

Pengelolaan pada kasus ini yaitu dengan pemberian obat, cairan, suportif, dan edukasi pada orang tua pasien. Sepsis merupakan keadaan darurat dimana penundaan pengobatan dapat menyebabkan kematian. Pengelolaan sepsis neonatal dengan antibiotik sebagai terapi awal yang mengacu pada jenis bakteri penyebab umum dan resistensi bakteri di setiap pusat kesehatan. Setelah hasil kultur darah diperoleh, jenis antibiotik yang menyebabkan kepekaan dan resistensi dapat disesuaikan. Kombinasi antibiotik diberikan untuk memperluas cakupan mikroorganisme patogen. Bila hasil kultur bakteri menunjukkan tidak terdapat pertumbuhan dalam 2-3 hari dan bayi secara klinis baik, pengobatan antibiotik harus dihentikan. Bila bayi dalam 2-3 hari keadaannya memburuk, harus dipertimbangkan untuk mengganti antibiotik golongan lain. ${ }^{20}$ Menurut protokol dari divisi neonati BLU RSUP Prof. Dr. R.D. Kandou Manado, antibiotik pilihan pertama ialah kombinasi amoxicillin dan gentamicin. Jika tidak terdapat perbaikan klinis, kombinasi ini dapat diganti dengan ceftazidime dan amikasin. Untuk infeksi yang berat dapat digunakan meropenem atau imipenem.

Saat pasien ini masuk RS, injeksi amoxicillin 2 x 125 mg dan injeksi gentamicin 12,5 mg tiap 36 jam telah diberikan. Oleh karena tidak terdapat perbaikan klinis 
maka pada hari ke-6 perawatan antibiotik tersebut diganti dengan ceftazidime $2 \times 125$ mg dan amikasin 2 × $20 \mathrm{mg}$.

Pada pneumonia neonatal ditemukan kesulitan bernapas (napas cepat, pernapasan berbunyi, kesulitan bernapas, pernapasan >60 kali/menit, retraksi dada, batuk, merintih) dan kultur darah positif, atau dua dari gejala berikut ini: faktor predisposisi (demam maternal $38^{\circ} \mathrm{C}$, cairan ketuban berbau busuk, ketuban pecah dini $>24$ jam), gambaran klinis sepsis (asupan makan berkurang, letargi, refleks menurun, hipotermi atau hipertermi, distensi abdomen), gambaran radiologik yang menunjukkan pneumonia, dan tanda sepsis positif (sel batang $>20 \%$ dari leukosit, hitung jenis leukosit di luar batas normal, peningkatan CRP, peningkatan angka sedimen eritrosit). ${ }^{21,22}$ Keputusan pengobatan empirik harus berdasarkan pada pola resistensi lokal, biaya, keuntungan, dan kemungkinan variasi regimen antibiotik. Pada pengobatan pneumonia neonatal termasuk sepsis neonatorum, WHO merekomendasikan pemberian ampicillin $(50 \mathrm{mg} / \mathrm{kg})$ tiap $12 \mathrm{jam}$ pada minggu pertama kehidupan dan tiap 8 jam pada 2-4 minggu, ditambah pemberian gentamisin sekali sehari.

Pada pasien ini didapatkan takipnea, penurunan aktivitas dan refleks, serta retraksi subkostal. Selain itu, pada pemeriksaan radiologik ditemukan infiltrat yang memperkuat diagnosis pneumonia neonatal. Pada awalnya pasien ini diberikan amoxicillin dan gentamisin tetapi karena tidak menunjukkan perbaikan klinis maka antibiotik tersebut diganti dengan ceftazidime dan amikasin. ${ }^{21,22}$

DSV merupakan penyakit jantung bawaan non-sianotik yang paling sering ditemukan dimana terdapat hubungan antara ventrikel kiri dan kanan. Riwayat maternal selama kehamilan sangat membantu diagnosis penyakit jantung kongenital karena kejadian-kejadian prenatal tertentu dapat bersifat teratogenik. Masa paska kelahiran sangat berperan dalam memberikan informasi untuk evaluasi keadaan jantung.,13

Beberapa kondisi saat kehamilan dan kelahiran yang berperan penting dalam terjadinya DSV pada bayi: ${ }^{23,24}$

1. Infeksi: infeksi rubella pada kehamilan trimester pertama; infeksi sitomegalovirus, herpes virus, koksaki virus B diduga teratogenik pada kehamilan dini, dan mengakibatkan miokarditis pada kehamilan lanjut; dan infeksi HIV.

2. Obat-obatan amfetamin, asam valproat, hormon (progesteron dan estrogen).

3. Alkohol terutama dalam kehamilan dini berhubungan dengan DSV.

4. Merokok walaupun belum terbukti teratogenik tetapi dapat menyebabkan retardasi pertumbuhan intrauterin.

5. Penyakit penyerta pada ibu yaitu diabetes melitus dan penyakit jantung kongenital.

Pada pasien ini didapatkan ibunya mempunyai kebiasaan minum alkohol sekitar $400 \mathrm{ml}$ dan merokok berkisar 5-6 batang per hari sejak kehamilan dini.

Pada keadaan normal, septum ventrikel berupa dinding utuh yang memisahkan kedua ventrikel. Klasifikasi DSV yang dikemukakan IDAI $^{11}$ dan Benson et $\mathrm{al}^{25}$ sebagai berikut:

1. DSV perimembran (berkisar $75 \%$ dari seluruh DSV) dibagi menjadi:

a. Defek perimembran inlet mengarah ke posterior ke daerah inlet septum

b. Defek perimembran outlet mengarah ke depan, di bawah akar aorta ke dalam septum pars muskularis

c. Defek trabekular mengarah ke bawah, kearah septum trabekularis

d. Defek perimembran konfluen yang mencakup ketiga bagian septum muskular sehingga merupakan defek yang besar

2. DSV muskular dibagi menjadi:

a. Defek muskular inlet

b. Defek muskular trabekular

c. Defek muskular oulet

3. Defek subarterial (doubly committed subarterial defect) terdapat tepat di bawah katub kedua arteri besar (aorta dan arteri pulmonal) 
Menurut ukurannya, DSV diklasifikasikan menjadi DSV kecil (luas defek $<5 \mathrm{~mm}^{2} / \mathrm{m}^{2}$ luas permukaan tubuh), sedang (luas defek $5-10 \mathrm{~mm}^{2} / \mathrm{m}^{2}$ luas permukaan tubuh), dan besar (luas defek lebih dari setengah diameter aorta atau $>10 \mathrm{~mm}^{2} / \mathrm{m}^{2}$ luas permukaan tubuh). ${ }^{11,25}$ Pada kasus ini didapatkan ukuran DSV 3,6 mm sehingga dikategorikan dalam DSV perimembran oulet kecil.

Umumnya bayi dengan DSV kecil tidak menimbulkan gejala. Gejala yang khas ialah ditemukannya bising jantung pada pemeriksaan fisik. Bising jantung bisa tidak ditemukan pada saat lahir karena resistensi vaskuler pulmonal tinggi dan perbedaan tekanan yang rendah antara ventrikel kanan dan kiri. Ketika resistensi vaskuler pulmonal menurun, aliran dari kiri ke kanan menyeberangi defek akan meningkat dan menjadi turbulensi sehingga menghasilkan suatu bising jantung. Bayi dengan DSV sedang dan besar akan memperlihatkan gejala sekunder berupa peningkatan aliran darah (edema paru) dan penurunan output. Pada pemeriksaan fisik bayi dengan DSV kecil atau sedang, biasanya ditemukan bising pansistolik grade 2-5/6, keras disertai getaran bising dengan pungtum maksimum di sela iga III-IV garis parasternal kiri yang menjalar sepanjang garis sternum kiri bahkan ke seluruh prekordium. Pada bayi dengan DSV besar sering terdapat takipnea dan menunjukkan tanda gagal jantung kongestif seperti kesulitan bernapas. Bising mid-diastolik pada DSV sedang atau besar diakibatkan oleh peningkatan aliran yang melewati katup mitral selama fase diastolik. ${ }^{8,12,26}$

Pemeriksaan radiologik biasanya normal pada DSV kecil. Pada DSV sedang dan besar ditemukan pembesaran jantung, konus pulmonal yang menonjol, peningkatan vaskularisasi paru, serta pembesaran pembuluh darah di sekitar hilus. ${ }^{26}$

Pada pemeriksaan elektrokardiografi, DSV kecil biasanya normal. Pada DSV sedang terdapat hipertrofi ventrikel kiri dan kadang-kadang disertai hipertrofi atrium kiri. Hipertrofi biventrikular didapatkan pada pasien dengan DSV besar dengan atau tanpa hipertrofi atrium kiri. Hipertrofi ventrikel kanan yang murni terjadi pada pasien dengan hipertensi pulmonal sekunder menuju obstruksi vaskular pulmonal yang diinduksi oleh sindrom Eisenmenger. ${ }^{8,9}$

Ekokardiografi merupakan baku emas untuk mendiagnosis DSV, antara lain bisa mengidentifikasi ukuran, lokasi dan jumlah defek, memperkirakan tekanan arteri pulmonal, serta mengidentifikasi defek lain yang berhubungan. Bila memungkinkan, dapat diambil lebih dari satu view dengan kombinasi dari long dan short axis views. Katup-katup jantung merupakan penanda penting dari tipe spesifik DSV, kecuali pada septum trabekular. DSV perimembran terletak dekat katup aorta. Pada apikal dan subkosta five-chamber views, DSV terlihat pada outflow tract dari ventrikel kiri, di bawah katub aorta. Pada parasternal shortaxis view di tingkat katup aorta, DSV terlihat berdekatan dengan katup trikuspid. Kesemuanya ini merupakan views yang paling baik untuk mengonfirmasi DSV perimembran., 8

Kateterisasi jantung diindikasikan pada pasien dengan peningkatan resistensi vaskular pulmonal. Tekanan arteri pulmonal dapat berbeda dari level normal ke sistemik. Pada DSV kecil, tekanan ruang jantung dan pembuluh darah dalam batas normal. Pada DSV sedang, tekanan arteri pulmonal mungkin masih dalam batas normal pada masa bayi, tetapi akan meningkat sesuai dengan pertambahan umur. Pemeriksaan angiokardiografi dapat menetapkan ukuran, jumlah, dan lokasi dari defek. ${ }^{8,9,13}$

Pengobatan medis diindikasikan bila terdapat tanda-tanda dan gejala gagal jantung kongestif. Penutupan spontan dapat terjadi pada $30-40 \%$ kasus dengan DSV perimembran dan muskular dalam enam bulan pertama kehidupan, dan lebih sering pada defek kecil. Sekitar 50\% dari DSV kecil akan menutup spontan pada usia dua tahun, dan $90 \%$ pada usia enam tahun. ${ }^{26,27}$

Dewasa ini penutupan melalui transkateterisasi lebih sering dilakukan. Amplatzer Perimembranous VSD Occluder device 
(APMVO) dirancang khusus untuk DSV perimembran berupa self expandable double disc device terbuat dari Nitinol wire mesh. APMVO tersedia dalam ukuran 4-18 $\mathrm{mm}$ dengan kenaikan setiap $2 \mathrm{~mm}$. Prosedur penutupan DSV perimembran melalui APMVO aman dan efektif. Komplikasi akibat pemasangan alat pada berbagai studi yang berbeda berkisar $0-5 \%$ dengan ratarata $1,2 \%$. Komplikasi yang dapat terjadi berupa embolisasi dari alat, perforasi jantung, dan trombosis vaskular. Embolisasi ini dapat terjadi bila alat dilepaskan sebelum waktunya atau berada pada posisi yang salah. Terjadinya perforasi jantung serta trombosis vaskular jarang dilaporkan. Right bundle branch block terjadi sekitar 6\% sedangkan complete heart block 0$3,7 \%$ setelah pemasangan alat. ${ }^{27,28}$

Penutupan melalui pembedahan dilakukan dalam usia 3-6 bulan pertama pada DSV besar dengan kardiomegali disertai gagal tumbuh, toleransi aktivitas buruk, gagal jantung kongestif yang tidak dapat diperbaiki dengan terapi medis, atau abnormalitas klinis lainnya dengan shunt yang nyata (>2:1) tanpa hipertensi pulmonal yang bermakna. Bayi dengan DSV kecil dan telah mencapai usia 6 bulan tanpa gagal jantung kongestif atau hipertensi pulmonal bukan merupakan kandidat untuk pembedahan. ${ }^{8,26}$ Kontraindikasi pembedahan ialah pasien dengan rasio resistensi

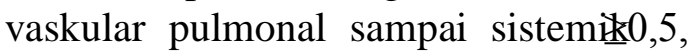
atau disertai penyakit obstruksi vaskular pulmonal dengan predominasi shunt dari kanan ke kiri. Mortalitas akibat tindakan pembedahan $<1 \%$. ${ }^{9,26,29}$

Pada pasien ini, diagnosis DSV kecil perimembran ditegakkan melalui ekokardiografi tanpa tanda-tanda gagal jantung kongestif. Disarankan untuk harus segera berobat bila pasien mengalami infeksi saluran napas akut dan diberikan antibiotik profilaksis untuk mencegah terjadinya endokarditis. $^{27,28}$ Ekokardiografi ulangan dilakukan pada usia satu tahun untuk mendeteksi apakah telah terjadi penutupan spontan. Bila penutupan defek belum sempurna, dapat ditunggu sampai 2-6 tahun selama tidak terdpat tanda-tanda gagal jantung kogestif. $^{26,27}$

\section{PROGNOSIS}

Prognosis pasien dari segi pneumonia dan sepsis neonatal dubia ad bonam. Penanganan sepsis dan pemberian terapi antibiotik empiris sejak hari pertama perawatan karena secara klinis telah ditemukan tanda-tanda sepsis neonatal. Selama observasi, terdapat perbaikan yang nyata dimana aktivitas dan refleks pasien membaik tanpa disertai sesak napas. Prognosis DSV kecil perimembran dubia ad bonam karena pada $50 \%$ kasus defek dapat menutup spontan pada usia dua tahun.

\section{SIMPULAN}

Telah dilaporkan kasus bayi laki-laki baru lahir dengan risiko sepsis yaitu:cairan ketuban kental dan berbau busuk, demam intrapartum maternal $\left(\geq 38^{\circ} \mathrm{C}\right)$, infeksi saluran kencing, dan fluor albus. X-foto toraks memperihatkan adanya infiltrat di parakardial kiri dengan jantung dalam batas normal, dan diinterpretasi sebagai pneumonia. Diagnosis kerja neonatus cukup bulan, sepsis neonatal, dan pneumonia neonatal. Diagnosis DSV ditegakkan melalui ekokardiografi dan tidak ditemukan adanya tanda-tanda gagal jantung kongestif. Prognosis pasien dari segi pneumonia dan sepsis neonatal dubia ad bonam karena telah diberikan penanganan sepsis sejak hari pertama dan adanya kemajuan secara klinis, sedangkan prognosis DSV kecil perimembran dubia ad bonam karena pada $50 \%$ kasus dapat menutup spontan saat usia dua tahun.

\section{DAFTAR PUSTAKA}

1. Zaidi AKM, Ganatra HA, Syed S, Cousens S, Lee AC, Black $R$, et al. Effects of case management on neonatal mortality due to sepsis and pneumonia. BMC Public Health. 2011;11:13-20.

2. Aminullah A. Sepsis pada bayi baru lahir. In: Kosim MS, Yunanto A, Dewi R, Sarosa GI, Usman A, editors. Buku Ajar 
Neonatologi (Edisi Pertama). Jakarta: IDAI, 2008; p. 170-85.

3. Kayange $\mathbf{N}$, Kamugisha E, Mwizamholya DL, Jeremiah S, Mshana SE. Predictors of positive blood culture and deaths among neonates with suspected neonatal sepsis in tertiary hospital Mwanza-Tanzania. BMC Pediatrics J. 2010; 10(39):1-9.

4. Thermiany AS, Retayasa W, Kardana M, Lila IN. Diagnostic accuracy of septic markers for neonatal sepsis. Paediatrica Indonesiana. 2008;48(5):299-305.

5. Benitz WE. Neonatal sepsis. In: Plin RA, Yoder MC, editors. Workbook in Practical Neonatology (Eighteenth Edition). Philadelphia: Saunders-Elsevier, 2007; p. 221-47.

6. Zaidi AKM, Ganatra HA, Syed S, Cousens S, Lee AC, Black $R$, et al. Effects of case management on neonatal mortality due to sepsis and pneumonia. BMC Public Health. 2011;11:13-20.

7. Kosim MS. Gangguan napas pada bayi baru lahir. In: Kosim MS, Yunanto A, Dewi R, Sarosa GI, Usman A, editors. Buku Ajar Neonatologi (Edisi Pertama). Jakarta: Badan Penerbit IDAI, 2008; p. 126-31.

8. Park MK. Left to right shunt lesions. In: Fletcher J, McGonigal C, editors. Pediatric Cardiology for Practitioners (Fifth Edition). Philadelphia: Mosby Inc, 2008; p. 212-21.

9. Darst JR. Miyamoto SD, Shaffer EM, Sondheimer HM. Cardiovascular diseases. In: Hay WW, Levin MJ, Sondheimer JM, Deterding RR, editors. Current Diagnosis \& Treatment Pediatrics (Nineteenth Edition). Denver: The McGraw-Hill Companies Inc, 2009.

10. Nembhard WN, Wang $T$, Loscala $M$, Salemi JL. Variation in the prevalence of congenital heart defects by maternal race/ethnicity and infant sex. J.Pediatr 2010;56:259-64.

11. IDAI. Defek septum ventrikel. In: Pudjiadi AH, Hegar B, Handryastuti S, Idris NS, Gandaputra EP, Harmoniati ED, editors. Pedoman Pelayanan Medis: Ikatan Dokter Anak Indonesia Volume 1. Jakarta: IDAI, 2010; p. 38-40.

12. Khalid M, Abdulla R. Ventricular septal defect. In: Abdulla R, editor. Heart disease in Children. London: Springer Dordiecht Heldeberg, 2011; p. 121-9.
13. Driscoll D, David J. Left to Right Shunts (Chapter 9). In: DeStefano FR, Bersin J, Consoli L, Harper J, Rivera B, Panetta A, McLaughlin HR, editors. Fundamentals of Pediatric Cardiology (First Edition). Rochester: Lippincott Williams \& Wilkins, 2006.

14. Damanik SM. Klasifikasi bayi menurut berat lahir dan masa gestasi. In: Kosim MS, Yunanto A, Dewi R, Sarosa GI, Usman A, editors. Buku Ajar Neonatologi (Edisi Pertama). Jakarta: IDAI, 2008; p. 11-27.

15. Stol B, Hansen N, Pablo J, Faix R, Brenda B, Krista P,et al. Early Onset Neonatal sepsis: The burden of group $\mathrm{B}$ streptococcal and E.coli disease continues. Pediatrics. 2011;127:817-26.

16. Benitz WE. Neonatal sepsis. In: Plin RA, Yoder MC, editors. Workbook in Practical Neonatology (Eighteenth Edition). Philadelphia: Saunders-Elsevier, 2007; p. 221-47.

17. Amir I, Rundjan L. Patofisiologi sepsis neonatorum: Systemic Inflammatory Response Syndrome (SIRS). In: Hegar B, Trihono PP, Irfan EB, editors. Update in Neonatal Infections. Pendidikan Kedokteran Berkelanjutan Ilmu Kesehatan Anak XLVIII. Jakarta: Balai Penerbit FKUI, 2005; p. 17-31.

18. Kusumasari N, Rohsiswatmo R, Gatot $D$, Darwis D. Incidence and risk factors for neonatal thrombocytopenia: a preliminary study. Paediatrica Indonesiana. 2010; 50:31-7.

19. Roberts I, Stanworth S, Murray NA. Thrombocytopenia in the neonate. Blood Reviews J. 2008; 22:173-86.

20. Edmond K, Zaidi A. New approaches to preventing, diagnosing, and treating neonatal sepsis. Plos Medicine J. 2010; 7(3):1-8.

21. Said M. Pneumonia. In: Rahajoe NN, Supriyanto B, Setyanto DB, editors. Buku Ajar Respirologi Anak (Edisi Pertama). Jakarta: Balai penerbit IDAI, 2010; p.354-5.

22. Sectish TC, Prober CG. Pneumonia. In: Behrman RE, Kliegman RM, Jenson HB, editors. Nelson Textbook of Pediatrics (Eighteenth Edition). Philadelphia: Saunders Elsevier, 2007; p. 1795-99.

23. Bruneau BG, Burn J, Srivastava D. Aetiology of congenital cardiac disease. In: Anderson RH, Baker EJ, Penny DJ, Redington AN, Rigby ML, Wernovsky G, 
editors. Paediatric Cardiology (Third Edition). Philadelphia: Churchill Livingstone Elsevier, 2010; p. 161-64.

24. Rudolph A. Ventricular septal defect. In: Kleinman C, editor. Congenital Diseases of the Heart Clinical Physiological Considerations (Third Edition). Chichester: Willey Blackwell, 2009; p. 156-77.

25. Benson LN, Yoo SJ, Habshan FA, Anderson RH. Ventricular septal defect. In: Anderson RH, Baker EJ, Penny DJ, Redington AN, Rigby ML, Wernovsky G, editors. Paediatric Cardiology (Third Edition). Philadelphia: Churchill Livingstone Elsevier, 2010; p. 591-623.

26. Bernstein D. Congenital heart disease. In: Behrman RE, Kliegman RM, Jenson HB, editors. Nelson Textbook of Pediatrics (Eighteenth Edition). Philadelphia: Saunders Elsevier, 2007; p. 1888-91.
27. Mullins CE. Transcatheter closure of ventricular septal defect. In: Cardiac Catheterization in Congenital Heart Disease: Pediatric and Adult. Massachusetts: Blackwell Publishing Inc, 2006. p. 832-40.

28. Diab K, Cao QL, Hijazi ZM. Device closure of ventricular septal defects (percutaneous and hybrid) using the Amplatzer VSD devices. In: Hijazi ZM, Feldman T, Cheatham JP, Sievert $\mathrm{H}$, editors. Complications during Percutaneous Interventions for Congenital and Structural Heart Disease. London: Informa UK Ltd, 2009; p. 175-83.

29. Corno AF, Festa P. Ventricular septal defect. In: Gasser A, editor. Congenital Heart Defects Decision Making for Surgery Volume 3 CT-scan and MRI. Würzburg: Steinkopff Verlag, 2009; p. 49-50. 